\title{
PUBLIC TRANSPORT: EFFECTIVITY OF COSTS AND A SPECIFIC CASE DESCRIPTION
}

\section{Ondřej Prchal*}

\begin{abstract}
Public transport is one of the driving forces of economic development; therefore, development and sustainability are required. In most cases, public transport operation is only possible with the help of public budgets, which in turn results in pressure from customers regarding efficiency. This article deals with the issue of public transport, especially in the Czech Republic, its sustainability and overall development. After an evaluation of the current situation for one specific case and possible future development, the author describes the basic survey conducted among passengers and outlines the possibilities for further development. The author made his basic observations and polled people who commute to work every day. In this case, the author attempts to show some basic connections and context.
\end{abstract}

Keywords: public transport, donations, ecology, mobility of inhabitants

JEL Classification: R41, R48

\section{Introduction}

In the Czech Republic, the public transport system is influenced by geographical conditions, the condition and density of infrastructure and, in particular, by the regional structure. The Ministry of Transport and the thirteen individual regions in the Czech Republic are both responsible for the infrastructure and ordering of regular public transport. In the case of infrastructure, an inconsistent approach to development and maintenance, which complicates its use, is an occasional problem. The most important aspect is the usability compared to the capacity, both technical and ordered. The Czech Republic has a specific unequal distribution of settlements and population density. From the point of view of this basic data, for example, the structure of towns and municipalities, it is immediately clear that without subsidies from the state budget it is impossible to ensure operation on public transport lines and the navigability and usability of the infrastructure. The volume of funds is limited, so there is social and political pressure to use them efficiently and maximise benefits (Brinke, 1999; Drahotský and Šaradín, 2003; Peková et al., 2011; Handy, 2016).

In the case of infrastructure, which is a key element in the planning of public transport lines, it should be noted that the main road arteries are administered by the Ministry of Transport, specifically, the organisations it establishes, namely the Road and Motorway Directorate of the Czech Republic. This organisation is responsible for all highways and first-class roads. Although it may seem at first glance that this infrastructure is of minimal importance to regional transport, the opposite is true. Due to the tracing of roads and highways, it is largely impossible to avoid their use. Railway lines are managed by Railway Administration, with the exception of a few cases,

* University of Economics, Prague, Faculty of Management (prco00@vse.cz). 
such as narrow-gauge lines or some other specifics. The second and third-class roads that cross regions even to the most remote settlements are managed by the individual regions. The regions also order regular public bus transport, passenger trains, fast trains as well as some express trains. On the other hand, the Ministry of Transport orders express trains, fast trains and international trains. Therefore, there is pressure on synergies and mutual coordination to ensure transfer links avoid duplication and concurrency, as well as the mutual coordination of infrastructure construction and maintenance. Many authors are concerned with public finances from the point of view of budget fulfilment and budget determination of taxes and finances of territorial self-government. The description itself does not list the areas covered by the national budgets, the sources of revenue and their structure or the budget approval process. The law states that regions, state organisational units or other territorial self-governing units should behave with the care of a proper manager. But nowhere is possible to find the optimal percentage part of public transport outgoings in the budget. This is due to the heterogeneity of transport systems across the regions, the state of the infrastructure, population density and cost phenomena. However, what is most important is the system of public budgeting, prioritisation or the existence of other significant expenditure areas.

In the case of the regions, it is primarily the area of health and education, which together with transport, are the three largest consumers of funds from regional budgets. A particular disadvantage is a frequent inconsistency in the attitude of elected representatives in key positions. There is currently no new legislation and regulations available at both national and European level. Due to price negotiations, these fixed amounts are fixed to a minimum, unmatched mileage for a set period, so there are no frequent changes in timetables or route routing. The sustainability of an efficient system is limited only by the amount of funds that the client receives for its operation and for multiple effects. The body is the main economic situation, unemployment, fuel prices and societal trends. All these attributes influence the interest in public transport, visiting and personal travel as a whole (Puga, 2002; Small and Verhoef, 2004; Small and Verhoef, 2007; CSO, 2016).

Especially in the last few years, there has been widespread discussion on the sustainability of passenger transport in terms of ecology and the environmental impact. If we abstract from the issue of air transport, which is not the subject of this text, we come to the issue of the preference of public transport over individual transport. Although only the adverse effects of individual transport are often taken into account, its contribution should also be taken into account, especially at the macroeconomic level. Low mobility in daily commuting is discussed in the Czech Republic as one of the problems of lower labour efficiency. However, it is not sufficient to only increase the total volume of service lines and public transport lines, it needs to coordinate the reconstruction and construction of new infrastructure.

New trends, such as alternative drives and clean electro mobility, also affect public transport. Depending on the size of the transport, the average daily rate, the condition of the infrastructure and the segmentation of the route, the customers decide between the different types of journeys and the types of vehicles. However, it is also necessary to take into account that the historical development in the given area or the state and the extent of already built technical infrastructure plays an important role. Therefore, it is important to find the optimal level of service provision and demand, given the state and extent of the infrastructure, the needs of the population and the volume of available funds in public budgets (Betsill, 2003; Dvořák, 2008; Hackbarth and Madlener, 2013). 
The issue of environmental sustainability is increasingly being discussed at regional, national and international levels. In cities, emission zones are increasingly being introduced to prevent vehicles with internal combustion engines below a specified level. So far, this measure only affects large cities. Another measure by local government representatives to regulate individual transport is the introduction of parking zones or, for example, disadvantageous parking rates for non-residents. However, all steps to restrict individual transport require strengthening public transport with all the accompanying elements. Otherwise, there will be a chain of problems such as a reduction in transport services, a reduction in the attractiveness of the site, with all the negative economic consequences (Hidrue et al., 2011).

Therefore, the author decided to describe the elementary problems of passenger transport in the defined region on a pre-selected route. The author intends to publish a broad description of the issue in his dissertation. For the purposes of this article, many aspects have not been taken into account and, overall, the issue has been described only from a narrow perspective without incorporating a broader concept.

\section{Methods}

In order to determine the optimal rate between the extent of ordered public transport links and the needs of the population, the author proceeded to analyse the data on traffic census and observation and questioning at exposed places. There were only three basic questions with an open answer for each person interviewed. The author evaluated this data according to his previous experience from praxis. These were specifically at the central public transport stop and in an area with a strong concentration of major employers. Another method for obtaining relevant data was an interview with representatives of several major employers in the area. In particular, the questions related to the distribution of work hours, regularity and the company's personnel policy. Specifically asked was whether there is any form of commuting support to the employed and, if so, in what form and what forms of transport does it apply to. This data was then compared with the behaviour of the employees of these companies.

A controlled interview was conducted with several respondents regarding the destination of the trip, preference and price sensitivity to the fare and fuel prices. For a basic comparison, a table with fares on the selected route was also given. I chose the secondary figure, namely the regulation on travel expenses issued by the Ministry of Finance, as the value of the cost of travelling by car. Prices of public transport were determined from the official price lists of the carriers operating on the routes.

\section{Results}

Based on the results of observation and questioning of individual respondents, it can be concluded that the biggest problem that handicaps public transport is travel time. Respondents also often mentioned the impossibility of making regular purchases at their places of residence in smaller villages and settlements. This is why they make these purchases on the way out of work in supermarkets on the outskirts of the city where there are good parking facilities. The answers from the employers' representatives showed that all the companies surveyed provided a commuter allowance for work of the same amount regardless of the form of transport. The only decisive attribute is the distance by which the contribution amount bands are determined. Public transport is mainly used 
by people who do not need to deal with other matters on the way, those who do not have a driving license or individuals who argue for cost-effectiveness. All public transport passengers surveyed replied that travel time was the biggest handicap. Reduced comfort in public transport was criticised, especially in the summer months, mainly due to the lack of air conditioning in some vehicles.

The monitoring of the individual transport operations found that more than $90 \%$ of the vehicles were occupied by the driver only. This implies that co-driving, although more economical, is not preferred. This is mainly due to the inconsistency of transport directions and the needs of individuals. In terms of travel time comparison, individual transport is also an advantage. Although available secondary data has shown that since the area is primarily accessible by a single road, traffic backlogs occur after the end of each shift, which means a delay of about five minutes. Of the forty randomly selected people, half of them headed for the car and the other half headed for the bus or train station or set out on a bicycle or on foot.

This disproportion clearly signals a major preference for individual transport despite its higher price. Price comparison per kilometre is very questionable. For the purposes of comparison, the author selected a model route on which it is possible to use a train, bus or a passenger vehicle. For comparison, prices of basic single tickets on the route are given. It should be noted that Czech Railways, in particular, offers a large number of discounts that make it worthwhile to make the daily commute. The price for using a vehicle is calculated as a model using the formula for calculating travel expenses. However, for the feasibility of the calculation, the author deducted $2.5 \mathrm{CZK}$ from the resulting amount, as the basic rate of compensation as the use of a passenger car also includes a proportional part of the sunk costs, such as insurance, amortisation, acquisition or regular repairs. However, most commuters own a passenger car for purposes other than commuting, so the author deducted this amount. Since the amount deducted is only about $25 \%$ of the total, it can be assumed that the cost of operating a vehicle after deducting sunk costs is even lower.

Table 1 | Comparison of three forms of transport

\begin{tabular}{|l|c|c|}
\hline Form of transport & Duration $(\min )$ & Price (CZK) \\
\hline Car & 45 & 100 \\
\hline Bus & 60 & 40 \\
\hline Train & 60 & 78 \\
\hline
\end{tabular}

Source: Author’s own processing according to Idos.cz (2019).

The table shows that there are large differences between the prices for different types of public transport, respectively between bus and train. The author describes this above. The currently valid Czech Railways pricelist is relatively disadvantageous for one-off fares without government-ordered or commercial discounts. However, there is no alternative for the occasional traveller. The author compared the travel time between the entrance gate to the premises of one of the major employers in the place and the pre-station area in the destination, respectively the time to get from the employer's building to the bus. The train stop is comparable to the time delay due to the traffic backlog on the driveway and is therefore neglected for the purposes of this article. 
The results of this measurement show that although a passenger car is the most timeefficient, a bus wins in terms of price. It is precisely the inconsistency of the tariff that can be evaluated as one of the biggest problems of contemporary public transport. Ordinary passengers do not perceive the difference between who is the customer. The basic attribute they pursue is reliability, timeliness and cost. The route on which the survey was conducted is specific in that it is operated by trains and buses, both in the public service obligation and at the commercial risk of the carrier. Although this is not a very typical example of Czech regional public transport, it is sufficient to describe the issue, as it is possible to emphasise the difference between individual modes of transport. It is precisely the fact that the carrier operates the route at a commercial risk that signals its attractiveness that generates enough passengers.

Measurement of the relationship between the volume of funds spent from public budgets and the overall benefit can only be measured in the long term. It is also necessary to take into account the coherence and integrity of the public transport network in the selected region. As the author points out, for example, along the route examined, the carrier also bears a commercial risk. This raises the question of whether ordering in the public service obligation is necessary at all. More on this topic is given in the following paragraph. Looking at the evolution of prices for road and rail transport services, it is clear that the pressure on public budgets is constantly increasing. Previously, the decisive item was the price of fuel and fuels in general. Today, it is labour costs that are rising every year due to a shortage of workers in this sector. In connection with the requirements of passengers and especially the customers, the costs of the acquisition and maintenance of new forms of transport are increasing, which are then budgeted by the carriers into the price of the transport performance. This is one of the reasons for the ever-increasing price of public transport in absolute terms. If the operator wants to keep the price competitive for the end customer competitive, then they must increase participation or take such measures that will lead to an increase in the number of passengers and thus an increase in the collection of fares.

\section{Discussion}

It results from the above investigation that any effort to quantify the benefits of increasing public expenditure on the public transport system is affected by a large number of variables. The decisive role is played by the attractiveness of the surveyed route, the state of the infrastructure, the existence of strong transport flows, but above all, the existence of an integrated transport system in the area. Of course, there is other macroeconomic data that more or less has an influence, such as unemployment, purchasing power parity or housing prices. This is especially in areas with high prices of private or rental housing where a stronger demand for daily commuting can be observed.

Public expenditure efficiency can be measured on a sample of one route or the whole system. In this example, it is possible to observe one rather unusual fact, namely that on a given route with the same crossing stops, the operator and its carrier operate at commercial risk. This in itself is not a basis for claiming that the public order is bad in this case. On the contrary, it is an incentive to discuss the concurrence of subsidised and commercial links on the same route. The system is set up so that the customer pays the carrier a fixed amount for the kilometres travelled. The amount is the same for any volume of passengers. Sales are either the client's property (the so-called gross contract) or remain in the carrier's account (the so-called net contract). In fact, at marginal times, commercial operators usually 
do not serve these lines because of a low load or the inability to fill the vehicle on the return journey. When transport is operated as a public service obligation, its primary purpose should be to provide service throughout the day, regardless of the service economy, provided that sufficient passenger interest is generated. Defining sufficient interest is a very sensitive topic. It is not possible to generally describe which transport stream can be considered sufficient, mainly because of different routing or routing through areas with different populations. There is also a different view of this criterion in the case of connections that ensure the transport of pupils to primary and secondary schools. In this case, the transport of one passenger is often an argument for maintaining the connection or part of the connection.

Generally speaking, determining the efficiency and scope of transport in such disparate regions as the Czech ones is usually impossible according to one key point. In densely populated regions around large cities, demand for these services is decisive and infrastructure capacity is often the limiting factor. In sparsely populated areas, a compromise between the client and the local authorities is often the decisive element. Therefore, it is a social policy with reference to the provision of basic services in the area. Representatives of large employers often interfere in the decision-making process. When this happens, the client tries to minimise the loss that this service generates, while representatives of municipalities strive to maximize the scope of service provision, as the issue often becomes a sensitive political issue. On the other hand, capacity constraints need to be taken into account. This is not only in terms of infrastructure capacity but also because the current situation on the labour market is not in favour of any large expansion of supply. On the contrary, the personnel problems in many places are reduced. This particularly applies to bus transport although recently there have been increasing cases where, due to a personnel outage, even train connections have not started, both in the Czech Republic and abroad.

Regular communication with representatives of schools, healthcare facilities, major employers and other organisations and clusters, such as national parks in tourist areas, is the basis for the correct distribution of connections between individual days of the week and the time of day. This originally occupied connections at specific times outside the peak rush hour, which were introduced at the request of the client, no longer have any use. The reason is often obvious. In many remote areas, for example, a doctor only works there one day a week. If connections were established only on this particular day at the request of passengers and the doctor changed the office day without this being reflected by the transport customer, there would be two problems at the same time. First, empty connections would be passing through the region because their purpose had lost its relevance and second, the mobility of the population would decrease, thus reducing their access to some services, in this case, the health service. The example shows the interdependence of individual aspects affecting the efficiency of public transport. Therefore, mutual rapid and effective communication between all stakeholders is extremely important and needs to be heavily focused on. The result will be an efficient use of public funds as well as an increase in benefits for the population.

Representatives of municipalities are the focal point for negotiations between regions, as they are the ordering parties for a large part of public transport and the residents. It should be noted that many public transport passengers are older people who do not make the most of modern communication technology to address their concerns directly to the client. Therefore, there is a need to enhance communication between local government representatives and citizens, as well as between municipalities and regions. 
This seemingly simple solution could help to improve, or at least prevent it from reducing, spending efficiency.

To conclude, the evaluation of efficiency within public goods, namely public transport, is dependent on many attributes. The first is the geographic form of the surveyed region, population density, the development and state of the infrastructure, the economic situation, demography and more. However, the cooperation of the transport ordered by important entities in the region, local authorities and citizens themselves is also important. If the amount of public goods, in this case, public transport, is allocated as much as possible in line with demand, there is at least a partial participation of the users in financing and thus a reduction in the burden on public budgets.

\section{References}

Betsill, M., and Bulkeley, H. (2003). Cities and Climate Change. London: Routledge.

Brinke, J. (1999). Úvod do geografie dopravy [Introduction to Transport Geography]. Praha: Karolinum.

CSO (Czech Statistical Office), (2016). Infrastruktura silniční dopravy v ČR a kraji k 1. 1. 2016 [Road Transport Infrastructure in the Czech Republic and the Region by 1 Jan. 2016]. [online] Czso.cz. Available at: https://www.czso.cz/csu/xc/infrastruktura-silnicnidopravy-k-1-1-2016 [Accessed 7 Mar. 2017]

Drahotský, I., and Šaradín, P. (2003). Dopravní politika [Transport Policy]. Pardubice: University of Pardubice.

Dvořák, P. (2008). Veřejné finance, fiskální nerovnováha a finanční krize [Public Finance, Fiscal Imbalances and Financial Crisis]. Praha: Beck.

Hackbarth, A., and Madlener, R. (2013). Consumer Preferences for Alternative Fuel Vehicles: A Discrete Choice Analysis. Transportation Research Part D: Transport and Environment, 25, pp. 5-17. https://doi.org/10.1016/j.trd.2013.07.002

Handy, S. (2016). Smart Growth and the Transportation-Land Use Connection: What Does the Research Tell Us? International Regional Science Review, 28(2), pp. 146-167. https://doi.org/10.1177/0160017604273626

Hidrue, M.K., Parsons, G.R., Kempton, W., and Gardner, M.P. (2011). Willingness to Pay for Electric Vehicles and Their Attributes. Resource and Energy Economics, 33(3), pp. 686-705. https://doi.org/10.1016/j.reseneeco.2011.02.002

Peková, J., Kunešová, H., and Hejduková, P. (2011). Finance územní samosprávy: teorie a praxe v ČR (Finances of Local Government: Theory and Practice in the Czech Republic). Praha: Wolters Kluwer.

Puga, D. (2002). European Regional Policies in Light of Recent Location Theories. Journal of Economic Geography, 2(4), pp. 373-406. https://doi.org/10.1093/jeg/2.4.373

Small, K.A., and Verhoef, E.T. (2004). Product Differentiation on Roads: Constrained Congestion Pricing with Heterogeneous Users. Journal of Transport Economics and Policy, 38(1), pp. 127-156.

Small, K.A., and Verhoef, E.T. (2007). The Economics of Urban Transportation. New York, NY: Routledge.

\section{Online Sources}

Idos.cz - https://idos.idnes.cz/vlakyautobusymhdvse/spojeni/ 